\title{
Do We Need To Worry About Wireless Devices: A Risk of Health?
}

\author{
Shabana Anjum* \\ CSIR-Indian Institute of Toxicology Research (CSIR-IITR), India
}

*Corresponding author: Shabana Anjum, Developmental Toxicology Laboratory, Systems Toxicology and Health Risk Assessment Group, CSIR-Indian Institute of Toxicology Research (CSIR-IITR), Lucknow, 22600, India

Submission: 悳 March 12, 2018; Published: 每 April 20, 2018

\section{Editorial}

In our country there are around 1.3 billion population and 1 billion populations are wireless device users. There are various wireless devices, like; cell phones, tablet PCs, audio players, digital cameras and the PC, all devices are used by Wi-Fi. A Smartphone, cell phone and Internet are an integral part of our daily life for most of the population. World Research Forum (WWRF) reports suggest 7 trillion wireless devices serving 7 billion citizens in 2017. There are approximately 7 billion population in the world are cell phone subscribers and serving wireless devices and around more than 5 million cell tower are installed in India, this is radiating a high power Electromagnetic radiation. Recent research has been suggested that a potential link between cell-phone radiation and cancer [1] and scientists left a lot of key questions unanswered. That includes how relevant the findings are to newer wireless technologies such as Bluetooth and WiFi that have become widespread since the study was designed in the early 2000s. Daily rapid use of mobile phone device affect the normal functioning of the biological systems of the human body and lead to serious problems such as: like cancer, brain tumor, Alzheimer's disease, Parkinson's disease and so on. short term effects of the wireless radiation causes hormone disruption, sleep disruption, cognitive impairment, behaviour, attention and long term effects cause DNA damage, infertility. This article summarizes the effect of high power cell tower radiation on human health effect. World Health Organization (WHO, 2006) has referred to approximately 25,000 articles published around the world over past 30 years, radio communications are a part of everyday life in today's society [2]. All radio communication systems utilize Electromagnetic field (EMF) in the radiofrequency (RF) part of the electromagnetic spectrum. (EMF) and (RF) waves Sources are present everywhere in our surroundings. The earth, sun, and ionosphere are all natural sources of EMF.

\section{Biological Effects and Human Health}

Human body consists of $70 \%$ of liquid, when our body comes under the electromagnetic radiation, it absorbs radiation, similar to the cooking in the microwave oven, where liquid part of the food is heated first that means molecule of the liquid part is collide to each other and these collision is the cause of heating. Similarly our body's liquid goes heated up and damage our tissue, causes several health hazards associated described in following [3]. The Blood Brain Barrier, Risk to Children and Pregnant Women, Irreversible infertility, Calcium ion release from cell membranes, DNA damage, Effect on Skin, Tinnitus and Ear Damage, Effect on Eye/ Uveal Melanoma, Cell phone emission weaken bones, Melatonin Reduction, Sleep Disorders, Neurodegenerative Diseases, Increase in Cancer risk Many of these are related to changes in the electrical activity of the brain [4] Dizziness, Palpitations of the Heart, Visual Disorders, Cardiovascular Problems, Buzzing in the Head, Altered Reflexes (Table 1).

\section{Table 1}

\begin{tabular}{|c|c|c|c|}
\hline $\begin{array}{c}\text { Name of } \\
\text { Deseased }\end{array}$ & $\begin{array}{c}\text { Year of the } \\
\text { Death }\end{array}$ & $\begin{array}{c}\text { Name of the } \\
\text { Deseased }\end{array}$ & $\begin{array}{c}\text { Year of the } \\
\text { Death }\end{array}$ \\
\hline $\begin{array}{c}\text { Radhabhai } \\
\text { sathe }\end{array}$ & 2005 & Breast Cancer & 66 \\
\hline Deshpandey & 2006 & $\begin{array}{c}\text { Oesopagus } \\
\text { Cancer }\end{array}$ & 48 \\
\hline $\begin{array}{c}\text { Shubhamji } \\
\text { Deshpandey }\end{array}$ & 2007 & Rectum Cancer & 66 \\
\hline Pujari & 2008 & Cancer & 46 \\
\hline Gawai & 2008 & Breast Cancer & 52 \\
\hline Shah & 2009 & Cancer & 48 \\
\hline Vidhyadhar Dev & 2009 & Liver Cancer & 52 \\
\hline Ransube & 2009 & Throat Cancer & 73 \\
\hline $\begin{array}{c}\text { Archana } \\
\text { Malvadkar }\end{array}$ & 2009 & Spinal cord & 17 \\
\hline
\end{tabular}

\section{Conclusion}

From all evidence accumulated so far, no adverse short or long term health effects have been shown to occur from the RF Signals produced by base stations. In September 2013, WHO have reported that no indication that environmental exposure to RF fields, such as from base stations, increases the risk of cancer or any other disease. 


\section{References}

1. https://www.cancer.org/cancer/cancer-causes/radiation-exposure/ cellular-phone- towers.html

2. WHO (2006) World Health Organization (WHO) in its Fact Sheet No. 304, Geneva, Switerland.
3. Kumar N, Kumar G (2009) Biological effects of cell tower radiation on human body. ISMOT, Delhi, India, pp. 678-679.

4. (2007) Mobile Telecommunications and health research programme (MTHR) Report. (c) (i) Creative Commons Attribution 4.0 International License

For possible submissions Click Here

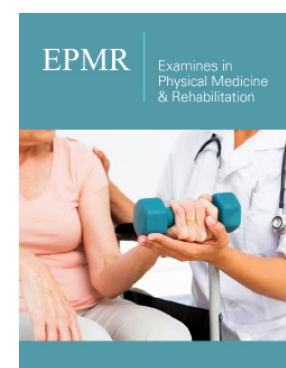

Examines in Physical Medicine and Rehabilitation: Open Access

\section{Benefits of Publishing with us}

- High-level peer review and editorial services

- Freely accessible online immediately upon publication

- Authors retain the copyright to their work

- Licensing it under a Creative Commons license

- Visibility through different online platforms 